\title{
The Capability Of Kepok Banana Peel (Musa Paradisiaca) To Triglyceride Level Decrease In Diabetic Rats
}

\author{
Indriawati \\ Physiology Medical and Health Sciences Faculty, \\ Universitas Muhammadiyah Yogyakarta \\ Yogyakarta, Indonesia \\ r indriawatiwibowo@yahoo.com
}

\author{
Khalifah \\ Medical and Health Sciences Faculty \\ Universitas Muhammadiyah Yogyakarta \\ Yogyakarta, Indonesia \\ zahratulkhalifah@gmail.com
}

\begin{abstract}
Dyslipidemia often follows the diabetic mellitus, such as primary dyslipidemia or secondary dyslipidemia. The increasing level of triglyceride can be seen in diabetes mellitus type 2. The therapy of diabetes mellitus use insulin. Now, all the people always talk about the herbal medicines, one of which is found in banana. Banana peel is only thrown away and has not been used. In fact the banana peel contains more beneficial components such as vitamin $\mathrm{C}, \mathrm{B}$ calcium, protein, pectin and flavonoid. The experiment about pectin has detected if pectin can totally decrease cholesterol. Hence, this experiment is important to analysis about the potential of extract kepok banana peel to decrease the triglyceride levels for Rattus novergicus induced with streptozotocin. This study was an experimental research with pre and post study design control design. 25 subjects, divided 5 groups became the sample used in this study. Data were analyzed descriptively to determine the effective dose and statistical analysis by Kruskal Wills and Wilcoxon Signed Rank Test. The analysis of the research results on the utilization of kepok peel banana extract showed a significant decrease of triglyceride $(p=0.043)$. The kepok banana peel extract in dose of $400 \mathrm{mg} / \mathrm{kg} \mathrm{BW} ; 200 \mathrm{mg} / \mathrm{kg} \mathrm{BW} ; 100 \mathrm{mg} / \mathrm{kg} \mathrm{BW}$ has been found to decrease the triglyceride level
\end{abstract}

Keywords-Diabetic mellitus, Dyslipidemia, Kepok Banana peel, Triglycerides.

\section{INTRODUCTION}

Type 2 diabetes mellitus is a metabolic disorder characterized by the high blood sugar levels caused by insulin resistance (caused by pancreatic $\beta$ cell failure) [1] [2]. In 2014, 9,116 people aged 20-79 years old in Indonesia suffered from DM Indonesia and 4,854 cases were undiagnosed [3]. WHO projected that the prevalence of diabetes cases will continue to increase up to $154 \%$ by 2030 [3][4].

Type $2 \mathrm{DM}$ is associated with various patterns of dyslipidemia either in primary dyslipidemia (due to genetic abnormalities) or in secondary dyslipidemia (due to DM, either due to insulin resistance or due to insulin deficiency) [5]. The main components of lipid abnormalities are the increase in total cholesterol, LDL cholesterol (low density lipoprotein), TG (triglyceride), and the decrease in the levels of HDL (High Density Lipoprotein). The commonest type of dyslipidemia in type 2 diabetes mellitus is the elevation of TG [6]. levels. During this time, type 2 diabetes mellitus is treated using insulin, which of course until now it still has some problems in terms of the high cost.

A treatment widely discussed today is herbal treatments, one of which is by using banana [7]. The waste of banana peel that is discarded continuously is not balanced with its processing. Every year, banana peel is wasted around $18-20 \%$. In fact, banana peel turns out to have vitamin $\mathrm{C}, \mathrm{B}$, calcium, protein, pectin and adequate fat. The results of a chemical analysis showed that banana skin contains $68.90 \%$ water, and $18.50 \%$ carbohydrates [8]. Several studies have been conducted on pectin; one of which is on the effect of tangerine peel pectin on hypercholesterolemia showing a decrease in total cholesterol, LDL cholesterol and HDL cholesterol [9]. While, research on the effect of kepok banana peel pectin on triglyceride levels, so far, is unknown.

\section{METHODS}

This research is an experimental study to test the potency of banana peel extract (Musa paradisiaca) on streptozotocininduced Rattus norvegicus with pre- and post-test control group design. Twenty-five white rats (Rattus norvegicus) were used as the tested samples induced with streptozotocin strain with five individuals per group. There were five groups: negative control group (without treatment), positive control group (metformin $10 \mathrm{mg} / \mathrm{kg} \mathrm{BW}$ ) treatment group of banana peel extract in dose of $100 ; 200 ; 400 \mathrm{mg} / \mathrm{kg} \mathrm{BW}$. The inclusion criteria was Rattus novergicus strain Sprague Dawley aged 2-3 months old with the weight in the range of 100 to 200 grams in male. Rattus novergicus died during the study was then excluded from the study sample. The free variable was banana peel extract in dose of $400 \mathrm{mg} / \mathrm{kg} \mathrm{BW}$, $200 \mathrm{mg} / \mathrm{kg} \mathrm{BW}, 100 \mathrm{mg} / \mathrm{kg} \mathrm{BW}$ for 14 consecutive days; while the dependent variable was the blood sugar level. Controlled variables were the 2-3-month-old Rattus novergicus with gender, weight, pellet, study site, examination time, and the same length of treatment.

The material used in this research was banana kapok peel (Musa paradisiaca) extract in dose of $400 \mathrm{mg} / \mathrm{kg} \mathrm{BW}$, $200 \mathrm{mg} / \mathrm{kg} \mathrm{BW}, 100 \mathrm{mg} / \mathrm{kg} \mathrm{BW}$, metformin, serum plasma of animal test, and streptozotocin. The tools used in this research included rat cage, scales, oral mouse sonde, spectrophotometer, syringe, micro capillary pipette, incubator, vertex, and centrifugation tube. Meanwhile, the tools used to extract pectin on banana kepok peel included static and clamps, thermometer, stirrer, heating mantle, threeneck flask, and oven. The research was conducted at Pharmacy Laboratory of Gadjah Mada University (UGM) and Inter-University Laboratory Centre UGM. The implementation began by providing 20 grams of fresh waste banana peel extract (wasted $<24$ hours). Subsequently, the skin of kepok banana was cooked to yellow before being cleaned and dried. Once dried, the banana peel skin was blended using a blender. The banana peel was added with the solvent according to the variable (Hydrochloric Acid and 0.05 
$\mathrm{N}$ sulfuric Acid) and then heated at $80^{\circ} \mathrm{C}$ for the time corresponding to the variables (1, 1.5, and 2 hours). Furthermore, screening was done to remove the sediment from filtrate. The filtrate was then added with ethanol and stirred until blended. Each of 1 liter concentrated filtrate was added with 1 liter of ethanol. Then, the precipitate was separated from the filtrate by using filter paper. Screening process was done several times to extract the maximum result. The filtration result was dried at $40^{\circ} \mathrm{C}$ for 8 hours.

25 tested animals were weighed, induced with streptozotocin in dose of $65 \mathrm{mg} / \mathrm{kg} \mathrm{BW}$ and divided randomly into 5 groups. Each group consisted of 5 Rattus norvegicus strains of Sprague Dawley. Group 1 was as negative control group without treatment, group 2 was as positive control group, given metformin $10 \mathrm{mg} / \mathrm{kg} \mathrm{BW}$; while group 3,4, and 5 were given banana peel extract respectively in dose of 400 $\mathrm{mg} / \mathrm{kg} \mathrm{BW}, 200 \mathrm{mg} / \mathrm{kg} \mathrm{BW}$, and $100 \mathrm{mg} / \mathrm{kg} \mathrm{BW}$ once in a day for 14 days. Blood glucose and triglyceride levels tested before and after treatment and data were analyzed using Wilcoxon test followed by Wilcoxon Signed Ranked and Kruskal Wills test.

\section{RESULTS AND DISCUSSION}

Table 1 shows the triglyceride levels before treatment. Triglyceride levels after streptozotocin induction were triglyceride levels before treatment. In day 12, each Rattus novergicus was treated according to each group for 14 days. In day 26 triglyceride levels were measured for the second time.

Table 1. Triglyceride levels before treatment

\begin{tabular}{clll}
\hline Groups & $\begin{array}{l}\text { Minimum } \\
(\mathrm{mg} / \mathrm{dl})\end{array}$ & $\begin{array}{l}\text { Maximum } \\
(\mathrm{mg} / \mathrm{dl})\end{array}$ & $\begin{array}{l}\text { Mean+SD } \\
(\mathrm{mg} / \mathrm{dl})\end{array}$ \\
\hline 1 & 125.55 & 139.42 & $131.24 \pm 0.50$ \\
2 & 105.75 & 131.39 & $117.94 \pm 10.86$ \\
3 & 124.09 & 132.85 & $128.47 \pm 3.42$ \\
4 & 100.44 & 134.31 & $124.53 \pm 12.80$ \\
5 & 126.50 & 159.10 & $139.45 \pm 10.78$ \\
\hline
\end{tabular}

Table 2. Triglyceride levels after treatment

\begin{tabular}{cccc}
\hline Groups & $\begin{array}{l}\text { Minimum } \\
(\mathrm{mg} / \mathrm{dl})\end{array}$ & $\begin{array}{l}\text { Maximum } \\
(\mathrm{mg} / \mathrm{dl})\end{array}$ & Mean+SD $(\mathrm{mg} / \mathrm{dl})$ \\
\hline 1 & 127.68 & 140.22 & $132 \pm 4.43$ \\
2 & 45.76 & 106.32 & $71.26 \pm 25.52$ \\
3 & 53.14 & 120.45 & $102.37 \pm 24.82$ \\
4 & 58.30 & 105.22 & $70.80 \pm 17.46$ \\
5 & 62.73 & 113.04 & $83.86 \pm 19.54$ \\
\hline
\end{tabular}

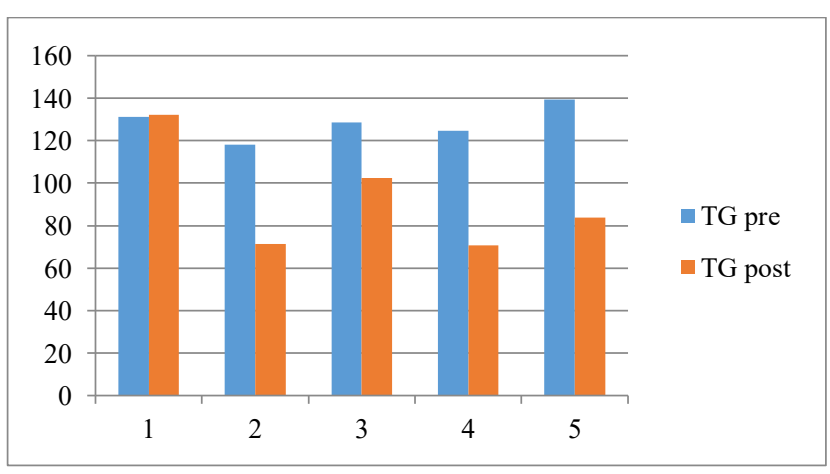

Figure 1. The triglyceride levels before and after treatment
Table 2 shows the sequential decline occurred in group 5 , group 4, group 2, and group 3. The least decrease in triglyceride levels was found in group 1 . This was due to the treatment given to each group. The DM group experienced a statistically significant change in blood triglyceride levels after streptozotocin induction. Table 2 shows the mean values of blood triglyceride levels after streptozotocin induction and after treatment. Changes in blood triglyceride levels as seen in Figure 2 showed the decrease of the blood triglyceride levels from post streptozotocin induction to post therapy. The group of DM mice without treatment (negative control) experienced an increase but 2 mice were still in the same value of triglyceride levels before streptozotocin induction.

The group of DM rat given metformin (positive control) experienced an average decrease in triglyceride levels of 46.68 and the Wilcoxon test showed a significant difference with $p$ value of 0.0432 . The administration of banana peel extract in dose of $400 \mathrm{mg} / \mathrm{kg}$ BW could reduce the blood triglyceride levels by 26.1 Wilcoxon test showed a significant decrease $(p=0.0432)$. The administration of banana peel extract in a dose of $200 \mathrm{mg} / \mathrm{kg} \mathrm{BW}$ could reduce the blood triglyceride levels by 53.73 Wilcoxon test showed a significant decrease $(p=0.0432)$. The administration of banana peel extract in dose of $100 \mathrm{mg} / \mathrm{kg} \mathrm{BW}$ could reduce blood triglyceride levels by 55.59. Wilcoxon test showed a significant decrease $(p=0.0432)$. The group treated with metformin was $10 \mathrm{mg} / \mathrm{kg} \mathrm{BW}$, which was given the treatment of banana peel extract in dose of $400 \mathrm{mg} / \mathrm{kg}$ body weight, which was given the treatment of banana peel extract in dose of $200 \mathrm{mg} / \mathrm{kg}$ body weight, which was given the treatment of banana peel extract in dose of $100 \mathrm{mg} / \mathrm{kg}$ body weight has a significant difference $(\mathrm{p}<0.05)$.

Rattus novergicus white mice Sparague Dawley strain induced by streptozotocin in dose of $65 \mathrm{mg} / \mathrm{kg} \mathrm{BW}$ induction was carried out peritoneal for five days. The administration of streptozotocin caused toxicities in pancreatic $\beta$ cells for $2-4$ days. Streptozotocin worked by forming a very reactive free form that could cause a damage to cell membranes, proteins, and deoxyribonucleic acid, causing the disturbance of insulin production by Langerhans pancreatic $\beta$ cells. ${ }^{10}$ The changes in blood glucose and insulin levels due to STZ induction were due to the abnormalities of $\beta$ cell function. STZ entered the pancreatic $\beta$ cells through the same receptor as glucose, GLUT-2, causing the blockage of glucose bond with GLUT2 by STZ [10].

Kepok banana peel extract could reduce triglyceride levels due to its content. Pectin contained in kepok banana peel could reduce blood cholesterol, one of which is triglycerides, supported by the study conducted by Frank Mattes that has proven that pectin can reduce the cholesterol levels in the blood [11]. The mechanism of action of pectin is that pectin is able to bind cholesterol found in the digestive system, thus preventing it from being absorbed into the bloodstream. The higher the pectin viscosity, the more effective it will be in absorbing cholesterol. Pectin with high viscosity will play a role in forming misela and bile acids with a low diffusion rate through a bolus to bind cholesterol in the digestive tract.

In addition, a decrease in blood triglyceride levels in groups 3, 4 and 5 occurred as a result of the increasing LPL activity. This was due to the effects of antioxidants found in kepok banana peel extract, which inhibited the occurrence of free radicals. Flavonoids, saponin and tannins from kepok banana peel extract are content that can reduce triglycerides 
by increasing the activity of LPL enzymes that function as antioxidants [12].

The increasing LPL enzyme activity will cause triglycerides in the chylomicrons to be hydrolyzed to free fatty acids and stored in adipose tissue [13]. According to Amic (2003) flavonoids as free radical scavenger have hydroxyl groups (OH-) in the aromatic ring and stop the peroxidation chain reaction lipids by protecting cells and chemicals in the body. The mechanism of action of antioxidants such as flavonoids lowers plasma cholesterol levels by inhibiting cholesterol in the intestine and increasing the reaction of bile acid formation from cholesterol to be excreted through feces [14].

Based on the Mann Whitney statistical analysis to determine the effective dose in the treatment, the results were obtained for the comparison of treatment groups with negative controls. The data showed some significant differences between the negative control group and positive control and treatment groups $(\mathrm{p}=0.0009)$. A significant comparison between the positive control group compared with the group given in dose of $400 \mathrm{mg} / \mathrm{kgBW}$ had a p-value $<0.05$, indicating a significant difference between the positive control group and the treatment group given in dose of $400 \mathrm{mg} / \mathrm{kg}$ and based on mean rank indicating the mean the positive control group was lower than the treatment group in dose of $400 \mathrm{mg} / \mathrm{kg} \mathrm{BW}$ so that the positive control group was more effective than the treatment group in dose of $400 \mathrm{mg} / \mathrm{kg} \mathrm{BW}$. While the comparison between the positive control group and the treatment group in dose of $200 \mathrm{mg} / \mathrm{kg} \mathrm{BW}$ had a p-value of 0.602 or $p>0.05$ showing no significant difference between the positive control group and the group given in dose of 200 $\mathrm{mg} / \mathrm{kgBB}$ and a comparison between positive control group and group the treatment in dose og 100 had a p-value of 0.251 or $p>0.05$ showing no significant difference between the positive control group and the treatment group given in dose of $100 \mathrm{mg} / \mathrm{kg} \mathrm{BW}$.

The results of this study showed the capability of kepok banana peel extract to reduce triglyceride levels in streptozotocin-induced mice for containing some substances such as pectin, and flavonoids. The effect of tamarind fruit extract on triglyceride levels, in this study resulted in the decreasing triglyceride levels due to the presence of substances such as flavonoids, saponin pectin also found in kepok banana peel in which in the study it was also the same with the one taking flavonoids, pectin as an analytical material that has the effect on the decrease of triglyceride levels[15].

\section{CONCLUSION}

The kepok banana peel extract (Musa paradisiaca) in dose of $400 \mathrm{mg} / \mathrm{kg} \mathrm{BW} ; 200 \mathrm{mg} / \mathrm{kgBW} ; 100 \mathrm{mg} / \mathrm{kgBW}$ decreased triglyceride levels and lowered triglyceride levels - not much different from metformin in dose of $10 \mathrm{mg} / \mathrm{kg} \mathrm{BW}$.

\section{ACKNOWLEDGMENT}

The authors would like to thank Yuli (InterUniversity Laboratory Centre UGM) for his technical assistance.

\section{REFERENCES}

[1] American Diabetes Association, "Diagnosis and Classification of Diabetes," Diabetes Care, 13: 67-74, 2013.
[2] I. Padberg, E. Peter, H. Witt, M. Mueller, T. Weis, and J. Wiemer, "A New Metabolomic Signature in Type-2 Diabetes Mellitus and Its Pathophysiology," PLOS ONE, 9(1): 1-12, 2014.

[3] P. Soewondo, A. Ferrario, and D.L. Tahapary, "Challenges in Diabetes Management in Indonesia: A Literature Review. Globalization and Health," 2012.

[4] P. Kartika, P. Andromedae, and T. Suhartono, "Pola Dislipidemia dan Hubungannya dengan Jenis Kelamin pada Penderita Diabetes Melitus Tipe 2 Di RSUP DR.Kariadi Semarang, Journal Undip, 1-3, 2013.

[5] Perhimpunan Dokter Spesialis Penyakit Dalam. "Petunjuk Praktis Terap Insulin pada Pasien Diabetes Melitus," Jakarta: PB PAPDI, 2013.

[6] V. Finivera, "Efektivitas Pemberian Seduhan Teh Rosela Merah (Hibiscus Sabdariffa L.) terhadap Kadar Hdl dan Ldl pada Rattus Norvegicus yang Diinduksi Aloksan.," Skripsi, Universitas Muhammadiyah Yogyakarta, 2011.

[7] H. Berry, H, Satria, and Y. Ahda, "Pengolahan Limbah Kulit Pisang Menjadi Pektin dengan Metode Ekstraksi,” J. Undip, 1-6, 2013.

[8] S. Maryanto, S. Fatimah., S., Sugiri, and Y.Marsono, "Efek Pemberian Buah Jambu Biji Merah Terhadap Produksi SCFA dan Kolesterol Dalam Caecum Tikus Hiperkolesterolemia," AGRITECH. 3(33): 334-339, 2013.

[9] Erwin, Etriwati, Muttaqien, T.W. Pangestiningsih, and S. Widyarini, "Insulin Expression in the Pancreas of Mice (Mus musculus) Induced by Streptozotocin Berulang. Kedokteran Hewan," 97-100, 2013.

[10] M. Frank,"Cholesterol and the Power of Pectin," USA: Hebstreith \& Fox Inc. Elmsford/NY, 2005.

[11] B.R. Sharma, L. Naresh, N.C. Dhuldoya, S.U., Merchant, and U.C., Merchant, "An Overview of Pectin. Times Food Processing Journal, June-July Issue, Page no 44-51, 2006.

[12] Khakim, "Ketoksikan akut ekstrak air daun benalu (Dendrophthoe pentandra (L.) Miq. dan Dendrophthoe falcata (L.f). Ertingsh) pada mencit jantan dan uji kandungan kimia," Skripsi. Faculty of Pharmacy, Universitas Gadjah Mada, Yogyakarta, 2006.

[13] A. Wahyudi, "Metabolisme Kolesterol Hati: Khasiat Ramuan Jat Belanda (Guazuma ulmifolia Lamk.) dalam Mengatur Konsentrasi Kolesterol Selular. Program Studi Biokimia. Fakultas MIPA. Institut Pertanian Bagor, 2009.

[14] Wahyudi, A. Cholesterol Metabolism of the Liver: Efficacy of Dutch Teak Herb (Guazuma ulmifolia Lamk.) In Regulating Cellular Cholesterol Concentration. Study Program of Biochemistry. Faculty of Mathematics and Natural Science. Institut Pertanian Bagor. 2009.

[15] T. Yokozawa, T. Nakagawa, and K. Kitani.," Antioxidative activity of green tea polyphenol in cholesterol-fed rats," J. Agri and Food Che, 50:3549-35, 2002. 